\title{
Liberdade de manifestação do pensamento e anonimato: funções e limites dogmáticos na Constituição Federal ${ }^{1}$
}

\author{
Freedom of speech and anonymity: functions and dogmatic limits in \\ the Federal Constitution \\ Libertad de expresión de pensamiento y anonimato: funciones y \\ límites dogmáticos en la Constitución Federal
}

Leonardo Martins ${ }^{2}$ Universidade Federal do Rio Grande do Norte (Natal, RN, Brasil) ORCID: https://orcid.org/0000-0002-1188-8194 E-mail: leonardomartins1@yahoo.de

\begin{abstract}
Lucas Catib de Laurentiis ${ }^{3}$
Pontifícia Universidade Católica de Campinas (Campinas, SP, Brasil) ORCID: https://orcid.org/0000-0001-6086-8491

E-mail: lucas.laurentiis@gmail.com
\end{abstract}

Felipe Grizotto Ferreira ${ }^{4}$

Pontifícia Universidade Católica de Campinas (Campinas, SP, Brasil) ORCID: https://orcid.org/0000-0002-4204-8569

E-mail: felipe.g.ferreira@hotmail.com

\footnotetext{
1 MARTINS, Leonardo; LAURENTIIS, Lucas Catib de; FERREIRA, Felipe Grizotto. Liberdade de manifestação do pensamento e anonimato: funções e limites dogmáticos na Constituição Federal. Suprema: revista de estudos constitucionais, Brasília, v. 1, n. 2, p. 75-111, jul./dez. 2021.

2 Professor Titular (Classe E) da Universidade Federal do Rio Grande do Norte e "Ambassador Scientist" da Alexander von Humbodt Foundation. Doutor em Direito pela Humboldt-Universität zu Berlin (2001), Alemanha. Currículo Lattes: http://lattes.cnpq.br/6963079630876141.

${ }^{3}$ Professor e coordenador do Programa de Pós-graduação da PUC-Campinas. Doutor em Direito pela Universidade de São Paulo. Currículo Lattes: http://lattes.cnpq.br/2294492760875997.

4 Mestre em Direito pela PUC-Campinas. Graduado em Direito pela PUC-Campinas, com período sanduíche na Universidade de Coimbra (Portugal). É advogado e possui experiência nas áreas de Direito Público; Direito Digital; Direito Civil e Empresarial e Proteção de Dados Pessoais. Currículo Lattes: http://lattes.cnpq.br/3074121320194357.
} 


\section{Resumo}

A partir de uma abordagem jurídico-dogmática, o presente trabalho analisa as funções e os limites da vedação de expressões anônimas na Constituição Federal (CF). A investigação é feita com base no método epistemológico geral da refutabilidade, o qual é aplicado às análises jurídico-dogmáticas das intervenções e seus limites nos direitos fundamentais. Por meio da revisão da literatura jurídica sobre o tema e de parâmetros da jurisprudência constitucional nacional, o trabalho sustenta duas interpretações alternativas para a vedação constitucional do anonimato. A primeira é categorizá-lo como uma reserva legal qualificada; enquanto a segunda, como um dever fundamental.

\section{Palavras-chave}

Liberdade de expressão; Anonimato; Direitos fundamentais; Crítica jurídica.

\section{Suimário}

1. Introdução. 2. Os desafios práticos e jurídicos do anonimato. 3. O texto e o contexto normativos do art. 5, IV, da CF: o estado atual da discussão. 4. A reconstrução da função dogmática da vedação do anonimato. 5. Conclusão.

\section{Abstract}

From a legal-dogmatic approach, this paper analyzes the functions and limits of the prohibition of anonymous expressions in the Federal Constitution. The investigation is based on the general epistemological method of refutability, which is applied to the legal-dogmatic analysis of interventions and its limits in the fundamental rights. Through a review of the legal literature on the subject and parameters of national constitutional jurisprudence, the work supports two alternative interpretations for the constitutional prohibition of anonymity. The first is to categorize it as a qualified legal reserve, while the second as a fundamental duty.

\section{Keywords}

Freedom of expression; Anonymity; Fundamental rights; Legal criticism.

\section{Contents}

1. Introduction. 2. The practical and legal challenges of anonymity. 3 . The text and normative context of art. 5th, IV of the CF: the current state of the discussion. 4. The reconstruction of the dogmatic function of the prohibition of anonymity. 5. Conclusion. 


\section{Resumen}

Desde un enfoque jurídico-dogmático, este trabajo analiza las funciones y límites de la prohibición de expresiones anónimas en la Constitución Federal. La investigación se basa en el método epistemológico general de refutabilidad, que se aplica al análisis jurídico-dogmático de las intervenciones y sus límites en los derechos fundamentales. Mediante una revisión de la literatura jurídica sobre el tema y los parámetros de la jurisprudencia constitucional nacional, el trabajo sustenta dos interpretaciones alternativas para la prohibición constitucional del anonimato. El primero es catalogarlo como reserva legal calificada, mientras que el segundo como deber fundamental.

\section{Palabras clave}

Libertad de expresión; Anonimato; Derechos fundamentales; Crítica jurídica.

\section{Índice}

1. Introducción. 2. Los desafíos prácticos y legales del anonimato. 3. El texto y contexto normativo del art. 5\%, IV del CF: el estado actual de la discusión. 4. La reconstrucción de la función dogmática de la prohibición del anonimato. 5. Conclusión.

\section{Introdução}

Brasil, 2016. Alguns usuários do Facebook criaram o evento "Virada Cultural na Casa de João Dória”, atividade que seria realizada em frente à residência do então Prefeito da cidade de São Paulo. Era um protesto contra a intenção do então prefeito, João Dória, de transferir a Virada Cultural paulistana para o autódromo de Interlagos. Simultaneamente a isso, foi criada uma página na mesma rede social denominada "Deixe a esquerda livre", espaço em que foram canalizadas diversas críticas ao governo paulista.

O prefeito moveu um processo contra o Facebook no qual pleiteava a retirada da convocação do evento e o fornecimento dos dados cadastrais dos criadores do evento e da página de esquerda. Curiosa não foi somente a atitude do Prefeito, que se mostrou preocupado com duas simples postagens de uma rede social que contém bilhões de usuários, mas também a decisão judicial que se seguiu. Isso porque, embora não tenha identificado nada de ilícito em ambas as publicações, o magistrado determinou que o Facebook compartilhasse os dados necessários à identificação dos usuários que se manifestaram de forma anônima na rede, 
pois, conforme a decisão, o anonimato seria (absolutamente) vedado no direito constitucional brasileiro (art. 5o, IV, CF). ${ }^{5}$

Outra decisão similar e recente envolve o Twitter. O periódico Jornal da Cidade Online foi desmonetizado em razão da atuação do movimento Sleeping Giants e, por isso, moveu processo em que solicita a suspensão do perfil e a identificação de seus administradores. Em sua decisão, a magistrada do caso não verificou nenhuma irregularidade na atuação do Sleeping Giants, mas determinou ao Twitter o fornecimento dos dados cadastrais e o IP dos administradores do perfil. O fundamento foi idêntico ao dos julgamentos anteriores: a expressão anônima não seria protegida em nível constitucional. ${ }^{6}$ Essas situações têm se multiplicado com o avanço da tecnologia digital. Decisões similares são recorrentes na prática judicial brasileira e geralmente têm a aceitação da dogmática nacional. $^{7}$

A defesa de uma vedação absoluta do anonimato na ordem constitucional brasileira não ocorre apenas no Judiciário. Seguindo a mesma linha de raciocínio das decisões mencionadas, o relator do "Projeto de Lei das Fake News" (PL no 2.630/2020), Senador Ângelo Coronel, afirmou que "nossa Constituição não está sendo cumprida. É vedado o anonimato. Não podemos permitir hoje que a pessoa entre numa plataforma, abra sua conta, crie um nome falso, crie uma caricatura e saia daí em diante depreciando, denegrindo, ferindo a honra das pessoas". ${ }^{8}$

O pressuposto subjacente, muitas vezes escondido e anônimo, do qual partem os adeptos de uma proibição absoluta do anonimato, para eles supostamente fundamentada na ordem constitucional vigente, mostra aqui a sua verdadeira face: quem fala sem se identificar ou seria covarde, ou teria algo errado, calunioso ou criminoso a dizer. A proibição do anonimato identificar-se-ia, assim, com o combate ao crime, a exigência de um debate sincero e a imposição de um dever ético de se exprimir a verdade. Como resultado, aquele que se apresenta ao público é identificado com a transparência, a verdade e a moral; ao contrário, o autor anônimo é incorreto, viciado e obscuro.

\footnotetext{
${ }^{5}$ Sobre o caso, ver: https://exame.com/brasil/justica-da-a-doria-direito-de-saber-quem-o-critica-na-web/.

6 PIRES (2020).

Entre muitos exemplos, todos no mesmo sentido, a esse respeito, ver: SARMENTO (2013, p. 260).

${ }^{8}$ Cf. NOVA... (2020).
} 
Em relação ao tema da responsabilização das plataformas digitais por abusos discursivos de terceiros, a questão do anonimato e dos pseudônimos é especialmente delicada, pois apenas faria sentido isentar de responsabilidade os provedores de conteúdo se fosse possível demandar diretamente os envolvidos por eventuais danos. ${ }^{9}$ Equalizar juridicamente a responsabilidade civil, as liberdades fundamentais e os aspectos técnicos que orbitam a internet e seus provedores de conteúdo não é tarefa simples, e a existência de comunicações anônimas é mais um ingrediente para apimentar essa enigmática receita. No direito brasileiro, o desafio cresce exponencialmente na medida em que existe a mencionada vedação expressa às manifestações do pensamento apócrifas no inciso IV do art. $5^{\circ}$ da Constituição Federal.

Para compreender corretamente o sentido e o alcance dessa norma constitucional, é preciso contextualizar a questão do papel social desempenhado pelo anonimato no exercício da liberdade de expressão. ${ }^{10} \mathrm{E}$, para desatar o nó criado por argumentos reducionistas do problema, é preciso compreender que o anonimato é algo muito mais próximo do cotidiano e dos valores reconhecidos pela sociedade.

Democracia, liberdades fundamentais e anonimato possuem íntimas relações. Um bom parâmetro inicial para se chegar a essa constatação está nos primórdios do próprio constitucionalismo. Os norte-americanos foram convencidos a adotarem a forma federativa de Estado pela enigmática escrita de Publius. Sob o manto desse pseudônimo, Alexander Hamilton, John Jay e James Madison publicaram diversos artigos em jornais durante os anos de 1787 e $1788 .{ }^{11} \mathrm{Na}$ literatura e nas artes os exemplos se multiplicam. George Orwell, Lewis Carroll, Stendhal, Pablo Neruda, Nelson Rodrigues e Machado de Assis são apenas alguns dos muitos autores que escreveram obras-primas sob o manto do anonimato.

\footnotetext{
9 Afirmando que essa situação representa um vácuo de responsabilidade: QUEIROZ (2021, p. 251). Sobre o tema e alguns de seus desdobramentos, conferir também: OMER (2014, p. 314).

${ }^{10}$ Liberdade de expressão é um termo amplo e, da perspectiva do direito comparado, diversos direitos comunicativos são reunidos sob tal epígrafe. Portanto, para fins da exposição e análise contextual do capítulo, adota-se o sentido delimitado pela Declaração Universal dos Direitos Humanos de 1948, a qual define a liberdade de expressão em seu artigo 19 como "a liberdade de, sem interferência, ter opiniões e de procurar, receber e transmitir informações e ideias por quaisquer meios e independentemente de fronteiras”. Da perspectiva jurídico-dogmática, é possível constatar a existência de diversos direitos para assegurar tais atos comunicativos, mas, desde que ciente disso, não há problemas jurídicos em se utilizar esse termo. Nesse sentido: MACHADO (2002, p. 370).

11 HAMILTON; JAY; MADISON (1937).
} 
Mais importante, contudo, é perceber as evidências das dinâmicas sociais subjacentes a essas experiências ilustrativas. Um indicativo disso está no fato de que o anonimato e os pseudônimos são importantes estratégias de participação política. Não são apenas o grande escritor e o importante autor que se ocultam do olhar do público e do poder. Aquele que denuncia grandes esquemas de corrupção, ${ }^{12}$ quem contesta de forma veemente o poder,${ }^{13}$ enfim, alguém que questiona as premissas do pensamento social e político consolidado, todos eles se valem e se valeram do anonimato, com o resultado da queda de regimes, governos e sistemas de opressão.

$\mathrm{O}$ anonimato existe para provar que o pensamento e a ideia valem mais do que a personalidade do autor; e aquele que escreve na condição do anonimato desafia a convenção social comum, de acordo com a qual o status e o local em que se encontra o falante conferem autoridade e poder ao argumento apresentado. É justamente o contrário, diz o autor anônimo, pois a partir do momento em que o nome e o status social pesam mais do que o conteúdo da mensagem, na medida em que conteúdos medíocres são exaltados, não pela originalidade da ideia, mas em razão da personalidade que escreveu ou falou, enfim, no momento em que ideias ou opiniões revolucionárias são proibidas e consideradas natimortas pelo simples fato de o autor não indicar o seu nome, ocorre uma inversão na ordem de prioridades da construção do pensamento e da ciência: a ideia e o raciocínio não têm mais valor autônomo, mas relativo.

Aquilo que se escreve e se pensa vale, desde que seja identificado com alguém que tem valor. Invertendo esta lógica, ao ocultar a identidade do criador, o autor anônimo chama a atenção para a criatura. Sem se apresentar ao público e sem apresentar títulos antes de argumentos, o escritor anônimo não somente faz com que o olhar do público se dirija ao conteúdo, como se iguala na condição do leitor, que sempre e necessariamente será um anônimo.

Escrito a seis mãos, este texto tem um quê de anônimo. Quem o lê não sabe se as ideias foram construídas por este ou por aquele autor. $\mathrm{E}$ a indeterminação

\footnotetext{
12 Foi o que ocorreu no conhecido caso Watergate, denunciado pelo informante anônimo "garganta profunda".

13 Exemplo notório a esse respeito está no artigo ácido ao presidente dos EUA publicado pelo The New York Times em 2018, pelo qual foram revelados supostos acontecimentos dos bastidores da Casa Branca. O autor se identificava apenas como um "alto funcionário" do governo daquele país. Em resposta, Donald Trump afirmou em suas redes sociais que o jornal deveria revelar a identidade do autor como medida de segurança nacional valendo-se, mais uma vez, do poder estatal como possível instrumento de silenciar seus opositores. Para acessar o artigo do auto anônimo, ver: TAYLOR (2018).
} 
da autoria se agrava quando se percebe que as ideias não surgem do nada. Elas são construídas por meio de debates, encontros e leituras. Isso quer dizer que todo pensamento é, portanto, essencialmente anônimo, conclusão que desafia a redação, de origem tão centenária quanto anônima, do art. $5^{\circ}$, IV, que une termos complementares ("pensamento" e "anonimato"), conectados por uma expressão disjuntiva ("sendo vedado”). O simples fato de o paradoxo inerente a essa construção não ser debatido pela dogmática constitucional brasileira já indica que há um problema na análise da definição do anonimato que, como consequência, resvala na compreensão da própria liberdade de manifestação de pensamento. Esta, afinal, é definida em oposição àquele. Portanto, sem que se saiba o que quer dizer "anonimato", é impossível desvendar o conteúdo da liberdade de manifestação do pensamento no direito brasileiro.

Com base no método epistemológico geral da refutabilidade e por meio de uma revisão da literatura jurídica sobre o tema e de parâmetros da jurisprudência constitucional nacional, este trabalho procura apresentar uma análise dogmática da questão, o que faz em três momentos. No primeiro deles, com o auxílio da literatura e de evidências extrajurídicas, são apresentados casos e problemas contemporâneos ligados à vedação do anonimato; no segundo, são analisadas as possíveis interpretações e classificações da norma da Constituição brasileira que, de maneira peculiar, veda o pensamento anônimo; finalmente, é apresentada uma compreensão que julgamos ser mais consistente e coerente com o sistema brasileiro de proteção de direitos e garantias fundamentais. Ao final deste percurso, espera-se que o anonimato não seja mais um conceito completamente estranho e, porque não dizer, desconhecido e anônimo, na literatura jurídica brasileira.

\section{Os desafios práticos e jurídicos do anonimato}

O exercício da liberdade de expressão e a efetiva participação política são facilmente coibidos por fatores políticos e sociais. Tão fundamental ao sistema e democrático quanto frágil e instável em seu exercício, esse direito é cotidiana e facilmente coibido com a mais simples ameaça de perseguição política ou sanção judicial. Ao menos essa é a constatação historicamente feita pela prática judicial europeia e norte-americana no âmbito da liberdade de expressão com a doutrina jurídica do chilling effect (efeito inibidor). ${ }^{14}$ Isso ocorre quando o titular do direito

\footnotetext{
${ }^{14} \mathrm{O}$ efeito é consolidado na jurisdição constitucional estadunidense. Entre os casos mais ilustrativos de sua aplicação, encontra-se: Estados Unidos da América (1964). Na jurisdição alemã, conferir: Alemanha (1995). Cf. os excertos e
} 
é dissuadido de participar de uma atividade comunicativa em decorrência de uma ameaça sancionatória. ${ }^{15}$

A proteção de manifestações anônimas do pensamento é uma ferramenta de atenuação desse efeito e tende, por isso, a fomentar a participação política e, portanto, a democracia participativa. Essa tensão entre formas de inibição de expressões, participação política e o papel das comunicações anônimas é, contudo, agravada com a difusão de redes sociais, nas quais ocorre o compartilhamento em grande escala de dados a respeito da vida quotidiana e a construção de tipos ideais de personalidade.

Criados para permitir que seus usuários angariem mais seguidores e consigam maior aceitação perante o público (na terminologia da rede, likes), os espaços de interação virtual se transformaram em fatores que moldam a conduta humana. Nesse contexto, quando grupos e indivíduos são taxados como “desviantes” nas mídias sociais, não será mais necessário que o Estado se encarregue de aplicar a sanção. A própria comunidade incumbir-se-á dessa tarefa de forma muito mais efetiva e rápida: quem se afasta do padrão de conduta será automaticamente tido como pária, sem que sejam necessários o devido processo ou o direito de defesa. ${ }^{16}$

Institucionalizada e radicalizada, a cultura de massa se torna a fonte de um mecanismo de vigilância permanente, voltado ao controle da conformidade da ação e do pensamento, que se mostra particularmente eficaz para direcionar a manifestação de opiniões e os demais processos comunicativos. ${ }^{17}$ Submetidos a constante pressão por reconhecimento e receosos de perseguições sociais decorrentes da expressão de seu pensamento, é altamente provável que os sujeitos falsifiquem suas ideias pelo bem da manutenção da visão de mundo prevalecente e da manutenção do status quo.

São esclarecedoras algumas evidências a esse respeito. Indivíduos ficam mais à vontade para conversar com estranhos em situações efêmeras do cotidiano - por exemplo, no táxi (Uber), elevador ou no assento ao lado em uma

\footnotetext{
anotações analíticas da última decisão em MARTINS (2018, v.2, p. 111-119).

15 Para uma visão geral do conceito de chilling effect e suas consequências jurídicas, ver: SCHAUER (1978).

16 Sobre os dilemas e aspectos da exclusão de indivíduos ou grupos nos contextos sociais, com considerações sociológicas e definições pertinentes: BECKER (1997, p. 10 ss.).

17 Sobre o papel da vigilância no controle da expressão, ver: SOLOVE (2003).
} 
viagem de ônibus - do que com os indivíduos efetivos membros de sua comunidade, na qual a identidade e a imagem do sujeito são fatores determinantes de sua aceitação. ${ }^{18}$ As pessoas censuram a si mesmas em prol de sua inclusão nos grupos a que pertencem ou querem pertencer. Por isso mesmo, a depender do tema e do contexto em que se expressa o pensamento, o anonimato representará um fator essencial para permitir a devida participação dos sujeitos no processo comunicativo.

Mídias sociais e as plataformas digitais oferecem material em abundância para essa reflexão. Voltado para a discussão de temas ligados à maternidade, o fórum online YouBeMom se tornou o ponto de encontro em que mães (pais também) podem discutir anonimamente os desafios, angústias e incertezas desse delicado momento de suas vidas. Ali, os temas e discussões que no ambiente analógico poderiam ser vistos como proibidos, ou como tabus, encontram um terreno fértil para a expressão, o debate e o reconhecimento das dificuldades enfrentadas pelos membros da comunidade. Falando, ouvindo e debatendo, de modo completamente anônimo, sobre temas como o aborto, o arrependimento da maternidade, a solidão e até mesmo a preferência por um dos filhos, os participantes do fórum se fortalecem como pais, desenvolvem um senso de pertencimento à comunidade, enfim, enriquecem o espaço público com a troca de experiências e a construção de uma visão realista e não romantizada da paternidade.

Em contrapartida, no Reddit, mídia social que também tolera o uso de pseudônimos e do anonimato, comunidades destinadas à violência e ao assédio infantil são comuns. ${ }^{19}$ Conexões e ações semelhantes ocorrem em movimentos contemporâneos que defendem a supremacia branca e o neonazismo, grupos que ameaçam pessoas e minorias pelo Twitter ou no aplicativo 4 Chan. ${ }^{20}$

Duas consequências decorrem disso tudo. Primeiro, as plataformas digitais permitem que indivíduos desviantes de determinada comunidade se tornem "normais" em suas comunidades online, pois eles facilmente se encontram e se

\footnotetext{
18 Esse fenômeno ficou conhecido na literatura das ciências sociais e comportamentais como "stranger-on-atraineffect". A esse respeito, conferir: RUBIN (1975).

19 Para uma comparação entre as plataformas e os respectivos usos do anonimato no contexto da dinâmica do espaço público, conferir: TUFEKCI (2017, p. 164-171).

20 Sobre tais movimentos e as tensões sociais por eles geradas, ver: MOORE (2018); ASCHER; UMOJA NOBLE, (2019, p. 170-188).
} 
conectam enquanto seus nomes permanecem ocultos. ${ }^{21}$ Segundo e mais crucial, do ponto de vista ideológico e político, o desafio jurídico decorrente do anonimato tem um sentido semelhante àquele colocado pela própria liberdade de expressão: ambos garantem que os mais diferentes e desviantes juízos de valor possam ser expressos sem serem censurados; ao mesmo tempo, ambos exigem do falante e do ouvinte uma postura de distanciamento mútuo. A liberdade de expressão pressupõe a neutralidade do ouvinte, ou do espectador. Por sua vez, o anonimato exige o desconhecimento, no sentido elementar de não identificação, do falante.

Fato é que a conjugação das tecnologias da informação com a internet não apenas multiplica os exemplos em que o anonimato é utilizado, mas também amplia os contornos da discussão a esse respeito. Por isso mesmo, é preciso repensar o elementar: o próprio conceito de anonimato. Na era digital, será que a mera possibilidade de ocultar o nome do emissor permite qualificar determinado conteúdo como anônimo? Ao que parece, não.

De fato, se os processos comunicativos e informacionais atingiram patamares nunca imaginados, os mecanismos de vigilância cresceram na mesma proporção. Com base na coleta e no cruzamento de dados coletados online, é possível traçar perfis inteiros de indivíduos e até mesmo de grupos. ${ }^{22}$ Por isso, o valor do anonimato é renovado. Sua função nunca residiu apenas na prerrogativa individual de não ser imediatamente identificado, mas na possibilidade de agir ou participar socialmente e, ainda assim, permanecer inalcançável à censura pública. ${ }^{23}$

O autor anônimo quer contribuir para o debate público sem ser taxado, classificado e segregado; seu objetivo é discutir anseios e pesadelos íntimos, desenvolvendo e expondo livremente seu pensamento, sem sofrer duras retaliações da comunidade. De forma paradoxal, mas real, o anonimato se apresenta aqui em sua função mais elementar: para se construir como indivíduo, o sujeito expõe seus sentimentos e pensamentos de forma mais pura e direta, fazendo-se conhecido do público naquilo que ele tem de mais natural, sem, contudo, se identificar.

\footnotetext{
${ }^{21}$ Nesse sentido, cf. TUFEKCI (2017, p. 169).

22 RODOTÀ (2008, p. 105). Exemplo de como operacionalizar um processo de identificação de discursos de ódio de neonazistas, conferir: ASCHER, Diana L.; UMOJA NOBLE (2019, p. 177-187).

${ }^{23}$ Nesse sentido, de longa data, conferir: NISSENBAUM (1999, p. 141-144).
} 
Por outro lado, se é que algum dia o anonimato foi, hoje ele não é mais algo absoluto. Na internet e nas plataformas digitais, ele subsiste em níveis, camadas e gradações. Utilizar um pseudoanônimo no Twitter e navegar pela internet no modo privativo são ações que oferecem um baixo grau de ocultamento; navegar por softwares com múltiplas camadas de criptografia, como o Tor, implica atos que permitem a realização de dinâmicas comunicativas dificilmente rastreáveis. ${ }^{24}$

Além dos distintos graus, existem diferentes objetivos e perspectivas do anonimato online. Uma coisa é o anonimato para interagir ativamente em comunicações e protestos pelas redes sociais. Outra é a garantia do anonimato para simples navegação pela internet (acesso à informação), situação que se assemelha muito mais com a necessidade de registro para ingresso em uma biblioteca do que com um artigo de jornal não assinado.

Finalmente, algumas considerações sobre a relação entre anonimato e privacidade. Primeiro, as diferenças: enquanto a privacidade geralmente é concebida como um direito humano e fundamental, o anonimato é visto não raras vezes como um instrumento para promoção de ilegalidades. ${ }^{25}$ Essa distinção é questionável, pois o conteúdo do direito não pode nem deve ser identificado ao instrumento que acompanha sua aplicação e garante seu exercício. É o que ocorre com as comunicações realizadas por particulares sob o manto do sigilo, condutas tuteladas pelo inciso XII do art. $5^{\circ}$ da CF.

O objeto dessa proteção constitucional é a exclusividade da comunicação particular do pensamento, o bem jurídico-constitucional correspondente ao aspecto de liberdade jusfundamental contemplado na chamada área de proteção do referido parâmetro do art. $5^{\circ}$, XII, da CF é a confiança na não participação a terceiros dos conteúdos comunicativos intercambiados por, ao menos, dois titulares do direito fundamental. Trata-se do complexo temático jusfundamental da privacidade como integrante do sistema de direitos fundamentais de personalidade, composto, além do dispositivo do inciso XII, também pelos incisos X e XI em possível combinação com o caput do art. $5^{\circ}$ da CF. ${ }^{26}$

\footnotetext{
${ }^{24}$ Para uma explicação dos meios de atuação anônima online, bem como de seus limites, ver: SARDÁ (2019, p. 558-559).

${ }^{25}$ COLEMAN (2019, p. 566).

${ }^{26}$ A respeito ver MARTINS (2016, p. 105-132).
} 
Trata-se, destarte, de um conteúdo que não se identifica ou se confunde necessariamente com o sigilo da comunicação de dados, ${ }^{27}$ embora tal sigilo componha também o mencionado subsistema de direitos fundamentais de personalidade. Consequentemente, o conteúdo da comunicação interpessoal pode ser tornado anônimo perante o público, sem que os dados e informações decorrentes dessa interação tenham de ser necessariamente abrangidos pelo sigilo. Em todo caso, os pressupostos de justificação de intervenções estatais em um ou outro parâmetro jusfundamental devem ser distinguidos tanto no que concerne ao alcance da respectiva tutela constitucional quanto em face de seus respectivos limites constitucionais. ${ }^{28}$

Da mesma forma, o sigilo da fonte (art. $\left.5^{\circ}, \mathrm{XIV}\right)$ é um instrumento que garante a não identificação da origem e do modo de colheita da informação (fonte no sentido probatório), sem que essa garantia se identifique com o direito protegido (liberdade de informação). ${ }^{29}$ Em um sentido mais amplo, propugna-se que a privacidade tenha um sentido instrumental, uma vez que protegeria a vida privada e esfera íntima do indivíduo. ${ }^{30}$

Mas ambos, privacidade e anonimato, possuem uma finalidade comum: evitar a vigilância constante e o controle incontrolável do Estado e da própria sociedade. Na literatura especializada se encontra, há algum tempo, o alerta de que o avanço das tecnologias da informação e a internet deixariam os indivíduos vulneráveis de maneiras antes inimagináveis. ${ }^{31}$ Os processos de vigilância em massa, como os revelados por Edward Snowden, vieram coroar tais prelúdios, com base no que se chegou a afirmar que nunca a sociedade esteve tão perto de viver em um grande panóptico, um mundo distópico orwelliano. ${ }^{32}$

Seja como for, a privacidade e o anonimato estão no topo das reivindicações políticas contemporâneas. ${ }^{33}$ Nesse contexto, fato é que o anonimato se apresenta como uma espada: pode ser usado para ferir, mas é ainda melhor para se

\footnotetext{
27 Com essa conclusão: FERRAZ JÚNIOR (1993, p. 444).

${ }^{28}$ Ver DIMOULIS; MARTINS (2021, p. 169 ss., 194 ss., 245 ss. e 291 ss).

29 Nesse sentido, conferir: GRIZOTTO; MARTINS; LAURENTIIS (2020).

${ }^{30}$ Para concepções jurídicas e filosóficas a respeito da privacidade, cf. SOLOVE (2008, p. 1-38).

31 RODOTÀ (2008, p. 21 e 65-73).

${ }^{32}$ HOROWITZ (2017, p. 39-62).

33 COLEMAN (2019, p. 567-571).
} 
defender. ${ }^{34} \mathrm{~A}$ tomada de consciência desse fato é o primeiro passo para se enfrentar de forma rigorosa os desafios jurídicos apresentados pelo anonimato. Sabendo que é inconcebível anonimizar o anonimato nas democracias contemporâneas, é preciso agora reconstruir o sentido dogmático da vedação constitucional brasileira do pensamento anônimo. Para isso, o primeiro passo é identificar as interpretações correntes dessa vedação e compreender os problemas jurídicos inerentes a cada uma delas.

\section{O texto e o contexto normativos do art. $5^{\circ}$, IV, da CF: o estado atual da discussão}

Quando se afirma ser "livre a manifestação do pensamento, sendo vedado o anonimato", surge uma série de questões jurídicas, as quais podem ser resumidas em dois problemas interpretativos. Primeiro, a conexão entre os períodos que compõem essa oração não é nem óbvia nem evidente: como ideias e pensamentos não têm dono e são construídas pelo debate e o confronto de argumentos, soa tautológico e até desnecessário exigir que o pensamento não seja anônimo. $\mathrm{O}$ pensamento já é, e naturalmente sempre foi, assim.

Aqui, convém realizar uma breve digressão histórica. Essa peculiar previsão da proibição do anonimato surgiu na Constituição de 1891. No seu art. 79, $\$ 12$, assegurava ser "livre a manifestação de pensamento pela imprensa ou pela tribuna, sem dependência de censura”, para logo em seguida, em frase apartada, dispor de modo direto: "Não é permitido o anonimato". A parte final do dispositivo não constava do anteprojeto elaborado pela comissão de juristas encabeçada por Saldanha Marinho e enviado ao Congresso Constituinte. Foi no substitutivo encomendado pelo Governo Provisório e elaborado por Rui Barbosa que a condicionante do anonimato foi inserida no texto constitucional. Desde então, à exceção do que se previu na Emenda Constitucional no 1/1969, tal cláusula permanece no direito brasileiro. ${ }^{35}$

\footnotetext{
${ }^{34}$ Essa analogia foi inspirada em: SARDÁ (2019, p. 561). Nesse artigo, os autores afirmaram que "[...] more broadly, in terms of social uses, online anonymity can be arguably compared to a weapon: on one hand, it can be used to harm; but on the other hand, it is an instrument for self-defense".

${ }^{35}$ Para um comparativo das redações do anteprojeto da Constituição de 1891 e o texto definitivo, conferir: BARBOSA (1946, p. 103).
} 
Segundo e como decorrência dessa primeira constatação, uma vez que se considere que o primeiro período não se refere exatamente ao pensamento, mas ao sujeito que pensa, fala, sente e manifesta suas ideias por meio de palavras ou gestos, a consequência será que o segundo período se refere à identificação prévia desse mesmo sujeito. Mas, se isso for correto, haverá uma contradição entre o qualificativo "livre" do ato da "manifestação de pensamento" e a vedação do anonimato, agora convertido em dever, ou mandamento, de identificação. Afinal, a conclusão a que se chega aqui será que a liberdade existe a partir do momento e desde que aquele que se manifesta identifique-se antes de manifestar seu pensamento.

É assim que o ato de pensar e exprimir o pensamento se converte no exercício de uma liberdade controlada e observada, voltada a possibilitar que o observador identifique aquele que expressa ideias desagradáveis e perigosas; não ao incentivo do debate livre de ideias. Como resultado, embora consista em apenas um dentre os inúmeros elementos normativos que compõem o sistema brasileiro de direitos e garantias fundamentais, ${ }^{36}$ esse dispositivo terá o poder de inverter a lógica da proteção de um elemento central do sistema constitucional de proteção dos direitos fundamentais: a liberdade de manifestação do pensamento se converte em liberdade controlada e vigiada do pensamento.

Em meio a esses problemas interpretativos, os esforços da literatura brasileira para enquadrar tal peculiar dispositivo às categorias da dogmática constitucional comparada são consideráveis. Incluído no rol dos direitos e garantias fundamentais, a liberdade de manifestação do pensamento deve, afinal, ser concebida como um direito destinado a garantir a autonomia individual ante as intervenções não autorizadas do Estado. ${ }^{37}$ Direito fundamental de resistência, a liberdade de manifestação do pensamento em sentido amplo assegura o exercício do direito, sem que o ato possa servir de fundamento para se sancionar o titular do direito. ${ }^{38}$

\footnotetext{
36 Exemplos de elementos normativos são encontrados nos incisos XIII ("qualificações profissionais”), XVI ("pacificamente, sem armas"), XVII (“fins lícitos").

37 Sobre o tema e com o enquadramento do dispositivo ao grupo de direitos classificados como "direitos de liberdade - status negativus”, conferir: SARLET; MARINONI; MITIDIERO(2018, p. 507-514); MENDES; BRANCO (2018, p. 388-389); SILVA (2021, p. 165-166). Para uma crítica a essa classificação e uma categoria alternativa, conferir: DIMOULIS; MARTINS (2021, p. 70-72 e 74).

${ }^{38}$ Por todos, nessa linha: MARTINS (2018, p. 93).
} 
Mas, se é certo que a análise da proteção e das restrições da liberdade de manifestação do pensamento é cercada de polêmicas catalisadas por situações limítrofes que se repetem no direito internacional e comparado, fato é que o sistema constitucional brasileiro se aparta dos demais justamente em virtude da proibição peremptória das manifestações anônimas. ${ }^{39}$ Como conciliar essa peculiaridade com a noção do direito fundamental à qual ela se encontra vinculada?

Salvo exceções pontuais, a jurisprudência brasileira tem interpretado essa vedação de modo literal, chegando à conclusão de que expressões anônimas são proibidas e, como consequência, ou o autor da mensagem deve ser compulsoriamente identificado, ou então a publicação deve ser bloqueada. ${ }^{40}$ Isso quer dizer que a identificação de fato ou ao menos potencial do autor é vista como precondição para o exercício do direito fundamental. ${ }^{41}$ Independente do conteúdo, contexto ou valor da expressão, sem que o autor se identifique, não há proteção constitucional.

O Supremo Tribunal Federal (STF) ainda não esclareceu de forma sistemática e abrangente o sentido e a extensão do parâmetro constitucional que veda o anonimato, ${ }^{42}$ mas o tema foi enfrentado na análise da validade de denúncias anônimas como base para a instauração de investigação criminal ou prova no sistema processual penal. ${ }^{43}$

Essa modalidade de denúncia tem sido utilizada como estratégia por diferentes instituições em diversas ocasiões justamente por mitigar o receio dos indivíduos em falar a verdade no contexto de um delito. Por outro lado, a denunciação caluniosa é um crime que pode ser apurado e sancionado tão

\footnotetext{
39 Uma pesquisa pelo termo "anonymity" no banco de dados do projeto "Constitute" reporta apenas quatro resultados. Entre eles, está a Constituição Federal de 1988 e a vedação do anonimato prevista em seu art. 5º IV. As demais constituições que aparecem são: Boliviana (2009), Suécia (1974) e Venezuela (1999). Além da Constituição brasileira, apenas a venezuelana, em seu artigo 57, proíbe o anonimato. A Constituição sueca, por outro lado, expressamente garante o direito ao anonimato em seu artigo $2^{\circ}$, do capítulo $10^{\circ}$. Disponível em: https://www.constituteproject.org/ constitutions?lang=en\&q=anonymity\&status=in_force\&status=is_draft. Acesso em: 21 set. 2021.

40 Apresentando algumas exceções a essa tendência: QUEIROZ (2021, p. 257).

${ }^{41}$ Nesse sentido, cf. SILVA (2021, p. 169-170).

42 Para a demonstração de que o STF não descreve suficientemente os parâmetros constitucionais nos casos de liberdade de expressão, ver: MARTINS (2012, p. 240-246).

${ }^{43}$ STF. HC 84827, 1a Turma, Rel. Min. Marco Aurélio, j. 7 ago. 2007.
} 
somente mediante identificação da fonte, ou sujeito, que difundiu a informação inverídica. ${ }^{44}$ Como conciliar essas exigências opostas?

Para sair dessa suposta encruzilhada, o STF criou um caminho intermediário: uma persecução penal não poderá ser instaurada com fundamento exclusivo em uma denúncia anônima, mas ela pode ser considerada uma importante evidência se for somada a outros dados e provas no mesmo sentido e, portanto, poderá embasar a instrução criminal. ${ }^{45}$ Fiando-se na tradição da dogmática brasileira, o Tribunal afirma aqui que a principal função desta vedação é possibilitar a responsabilização civil ou penal de autores de conteúdos ofensivos. ${ }^{46}$ Essa orientação está longe de apresentar parâmetros normativos que permitam um enquadramento coerente e controlável do texto constitucional que veda as expressões anônimas.

De fato, se o anonimato for realmente vedado em nível constitucional, qualquer manifestação anônima enquadrada no inciso IV do art. $5^{\circ}$ da CF não terá nenhum valor jurídico, não importa se acompanhado ou não de outros elementos de prova. E, uma vez que a invalidade da origem da colheita de provas contamina a cadeia probatória, a investigação fundamentada, em sua origem, em uma denúncia anônima seria, de acordo com essa linha de raciocínio, completamente inválida. ${ }^{47}$

O ponto nodal, que escapa à atenção tanto da dogmática quanto da jurisprudência brasileiras, é que a denúncia anônima não tem absolutamente como ser enquadrada no dispositivo de "direito fundamental" em tela. Em termos técnicos, a denúncia anônima não é abarcada pelo âmbito de regulamentação do direito fundamental do art. $5^{\circ}$, IV, da CF. Com efeito, a manifestação do pensamento a que se refere o dispositivo constitucional é aquela que expressa juízos de valor acerca de fatos, ideias, outras opiniões etc. Não se trata aqui nem da liberdade de consciência e crença (inciso VI) nem do ato de comunicação privado e individual (inciso XII), mas da manifestação que, em tese, tem o condão de afetar a imagem

\footnotetext{
${ }_{44}$ Por muitos, afirmando que é necessário o término do inquérito policial originário, ou da ação penal que a ele se seguiu, para que nova notícia-crime seja processada: NUCCI (2017, p. 1117).

${ }_{45}$ Com esse entendimento, no julgamento do HC no 84.827/TO, o STF suspendeu uma notícia-crime formulada pelo Ministério Público Federal por se fundamentar exclusivamente em denúncia anônima.

46 STF, MS 24369 MC, Decisão Monocrática, Rel. Min. Celso de Mello, j. 10 dez. 2002.

47 Esboçando este argumento, mas reconhecendo que a jurisprudência do Supremo relativiza essas conclusões: BADARÓ (2017, p. 124).
} 
e a respeitabilidade pública de quem se considera atingido pelo pensamento manifestado. É justamente essa a razão da previsão constitucional - o medo de que a liberdade de manifestação de opiniões, publicáveis em veículos de comunicação social, sobretudo mediante um exercício da liberdade que se ocupe de assuntos políticos com acidez e veemência, seja utilizada de "forma abusiva". 48

Que não se pode, ao mesmo tempo e sem contradição, partir dessa pressuposição e também garantir a liberdade de manifestação de pensamento, é a charada criada pelo constituinte brasileiro. Mas esse paradoxo constitucional não precisa ser inserido e debatido em inquéritos criminais, que, desde que baseados em evidências que indiquem a materialidade e a autoria delitivas em concreto e de forma específica, não devem ser contaminados pelo fato de nem todas as afirmações lá utilizadas terem fonte identificada.

Uma notícia-crime ou congêneres não têm absolutamente nada a ver com o campo da realidade social sobre o qual incide o art. $5^{\circ}$, IV, da CF. Sem embargo da espécie que causa ler em uma norma definidora de um clássico "direito fundamental" uma vedação de conduta de seu titular, essa vedação pode ser entendida, como se verá, como limite constitucional ou até definição assistemática de um dever fundamental pelo constituinte. Transpor geral e abstratamente a vedação do anonimato para constelações absolutamente estranhas ao clássico direito fundamental em tela, como a notícia anônima de um crime, simplesmente corresponde a uma construção jurídica das mais obtusas.

Enfim, se e quando forem constatados indícios da prática do crime de denunciação caluniosa, seja em sua forma original, seja em sua nova modalidade eleitoral ${ }^{49}$ será necessário abrir nova investigação para se verificar a autoria e a materialidade da conduta, questão que não se identifica com a admissibilidade da denúncia anônima, afinal crimes ocorrem, entre eles os crimes de expressão (injúria, difamação, calúnia), tanto em situações em que o emissor da mensagem se identifica, quanto em situações em que essa identificação não ocorre.

Ao contrário, pode haver crimes variados, em que o autor quer ser identificado (atos terroristas ou a incitação à violência ou à perseguição de minorias,

\footnotetext{
48 Esta pressuposição parece ter como raiz história as críticas contundentes de Rui Barbosa ao jornalismo brasileiro do início do século XX, que, de acordo com o autor, seria irresponsável por estar contaminada pela "peste negra" do anonimato: BARBOSA (1949, p. 226).

49 Prevista no altamente problemático artigo 326-A do Código Eleitoral.
} 
hoje e ontem praticados à luz do dia). Em todas essas situações, é assunto do processo penal e dever da autoridade pública conduzir as investigações de forma controlada e transparente para, se possível, identificar os autores e as circunstâncias em que foi praticado o delito. O direito constitucional não exerce nenhum papel nesse campo: sua função é puramente de contenção, não de determinação de tudo aquilo que deve ser feito pela autoridade em sua atividade quotidiana.

Na literatura constitucional brasileira, à exceção de análises recentes que procuram categorizar os graus de anonimato e as possíveis intervenções destinadas a coibir essa forma de expressão, ou buscam razões para justificar a proteção da manifestação do pensamento anônima em teorias gerais dos direitos fundamentais, ${ }^{50}$ persistem as considerações que vinculam a necessidade da proibição do anonimato à necessidade de eventual reparação de danos ou buscar justificar a imposição de pena em razão da possibilidade de exercício abusivo da liberdade de expressão. ${ }^{51}$

Segundo essa opinião dominante, o inciso IV é interpretado em conjunto com o inciso $\mathrm{V}$ do art. $5^{\circ}$ da CF, de modo a gerar um todo semântico, de acordo com o qual: $i$ ) a liberdade de expressão existe e pode ser exercida como direito fundamental, desde que seu titular não ultrapasse os limites e fins indicados pela própria constituição; ii) por ser vinculada a um fim (não ser utilizada de "forma abusiva"), a liberdade de expressão se transforma em um direito funcionalizado (dienende Freiheit), que existe à medida que o fim a que ela se destina for cumprido; $^{52}$ iii) a relação de preferência (princípio distributivo) ${ }^{53}$ entre a norma de proteção da liberdade e a restrição estatal que sobre ela incide se inverte, pois, de acordo com a lógica adotada pela dogmática brasileira, cabe ao titular do direito fundamental indicar que a expressão por ele utilizada não ultrapassou os limites "razoáveis" e não se tornou, por isso mesmo, uma manifestação do pensamento "inconstitucional", como se fosse possível uma fala, ou um ato, ser avaliado em

\footnotetext{
50 Nessa linha, propondo a reinterpretação do parâmetro constitucional com base na teria de Ronald Dworkin: MONTEIRO (2017).

51 Por todos, afirmando que a liberdade de expressão é acompanhada de um ônus: SILVA (2012, p. 92). De modo similar, sustentando que o modelo brasileiro de proteção da liberdade de expressão é o da "liberdade com responsabilidade": SARLET; MARINONI; MITIDIERO (2018, p. 527); NOVELINO (2012, p. 514); SARMENTO (2013, p. 528-529); FARIAS (2001, p. 165-166).

52 Crítico no que diz respeito aos efeitos desta noção sobre a estrutura de proteção dos direitos fundamentais: HARTMANN (2016, p. 22).

53 Para uma reconstrução histórica de tal noção, ver: LAURENTIIS (2017, p. 54).
} 
termos de constitucionalidade, quando somente normas, não ações ou fatos, podem ser avaliadas e sancionadas no que diz respeito à sua constitucionalidade. ${ }^{54}$

Assim, ao se adotar a ideia de "liberdade com responsabilidade", a identificação do autor e a proibição do anonimato incidem de forma automática como um "dever constitucional" que impõe ao titular uma conduta diretamente vinculada ao direito, o que em termos estruturais e dogmáticos significa tratar o titular dos direitos fundamentais também como o destinatário da norma de proteção e, assim, do dever dela decorrente. Uma inversão de perspectivas que compromete a lógica de resistência a intervenções estatais que subjaz à garantia não apenas da liberdade de manifestação do pensamento, mas de todos os direitos fundamentais.

Essa compreensão comporta algumas variações. Em uma versão mais radical, há quem considere que, apesar de a vedação ao discurso anônimo estar presente apenas no inciso IV do art. $5^{\circ}$, sua aplicação deve se estender sobre o exercício de todo e qualquer direito fundamental "comunicativo" previsto na CF. ${ }^{55} \mathrm{O}$ resultado disso é que todas as condutas previstas nos incisos VI, IX, XII, $\mathrm{XVI}$, todos do art. $5^{\circ}$, e também aquilo que se prevê no art. 220 da CF, poderiam ser realizadas tão somente se presente a identificação das pessoas envolvidas. Livros, obras de arte, grafites, estudos científicos, tudo isso será permitido pelo direito constitucional brasileiro (transformado aqui em uma espécie de "Grande Irmão", que observada tudo e todos), desde que o autor das obras se identifique completamente. Tendo em vista o dever do intérprete de observar o sistema de proteção e de limites, tal qual firmado pelo constituinte, com a consequência do princípio de vedação absoluta da transposição e intercâmbio de limites entre os específicos parâmetros jusfundamentais, essa é uma posição que carece de fundamento, devendo ser descartada.

De outra perspectiva, há quem defenda a desnecessidade de identificação específica e individualizada de cada publicação, pois isso levaria à extinção da prática do jornalismo. O que a vedação constitucional impõe seria, nessa linha de raciocínio, apenas a identificação de um responsável pelas publicações, mas não necessariamente precisaria ser o real autor do conteúdo abusivo. ${ }^{56}$ Também

\footnotetext{
${ }^{54}$ Em sentido contrário, afirmando que somente atos estatais emanados de autoridades estatais podem ser avaliados com base em parâmetros constitucionais: POSCHER (2003, p. 173).

55 SARLET; MARINONI; MITIDIERO (2018, p. 527).

56 FARIAS (2001, p. 168).
} 
no caso dessa opinião, trata-se de uma apreciação "pragmática" ou "consequencialista" totalmente aleatória.

Desse modo, uma primeira crítica a esse conjunto de proposições decorre da falta de mínimo rigor dogmático em suas tentativas de fundamentação. Para se excluir a proteção de um direito fundamental, não basta pressupor que a liberdade de manifestação de pensamento, a liberdade artística, a liberdade de imprensa ou a liberdade de reunião podem causar danos à honra, à imagem ou à personalidade de terceiros. É preciso indicar o fundamento jurídico dessa pressuposição, até porque, sem esse elemento, não há como se afirmar que a conduta (manifestação anônima) é ilícita, tendo como parâmetro a legislação infraconstitucional. Acresça-se que tal ilicitude ainda pode ser afastada no bojo de seu controle abstrato e concreto (sua interpretação e aplicação pela Administração e Judiciário) em face do parâmetro jusfundamental, dotado sabidamente de supremacia normativa, de modo a vincular os legisladores civil, penal e administrativo e, naturalmente, todos os órgãos executivos e judiciais, intérpretes que são da legislação ordinária.

Em paralelo, sob o ponto de vista da construção e estrutura do art. $5^{\circ}$ da $\mathrm{CF}$, não há como se pressupor que o fato de o inciso IV (que garante a liberdade e veda o anonimato) ser seguido do inciso $\mathrm{V}$ (que assegura o direito de resposta e a indenização pelo dano moral e material) gera consequências práticas decisivas. Primeiro porque a simples ordem sequencial de dispositivos (incisos) não pode definir seu sentido - ser a casa o "asilo inviolável do indivíduo" não muda as condições de acesso à comunicação telefônica e telegráfica. E o contrário também é certo, pois há incisos completamente apartados (IV, IX e XIV) que tratam de temas próximos e podem, de alguma forma, ser interpretados em conjunto.

Por outro lado, ao se assegurar o direito de resposta e a indenização decorrente do dano material, moral ou à imagem, a CF não indica quem deve arcar com essa responsabilidade e não se pode pressupor que ela sempre e necessariamente recairá sobre o autor. No caso de obras anônimas, tal responsabilidade recairá sobre o editor da obra, por exemplo (Lei no 9.610/1998).

Da mesma forma, na internet, a responsabilidade de provedores de conexão ocorrerá se, após ordem judicial, o conteúdo lesivo não for retirado da plataforma. Aqui, mais uma vez, a responsabilidade pela divulgação de conteúdos de autoria anônima existe, mas a condenação à indenização dela decorrente deve ser requerida na forma e nos limites descritos em lei. O que não se pode admitir 
é que sejam permitidos casos de responsabilidade e eliminação de conteúdos fora dos parâmetros legais, caso contrário sempre será possível afirmar que as condições para a responsabilização adequada pelo dano não foram satisfeitas (no caso de um dano realizado por um menor órfão, ou por pessoas sem patrimônio suficiente para ressarcir o titular, por exemplo), do que se seguirá que o próprio texto constitucional abrirá as portas da caixa de pandora que servirá para a eliminação da liberdade de expressão.

Mas a exclusão do anonimato gera outros problemas interpretativos. Primeiro porque, em termos estritamente constitucionais, o seu sentido prático é duvidoso. Afinal, para que ocorra a incidência da norma de proteção do direito fundamental, é necessária (i) a identificação da área de proteção e (ii) a existência de uma intervenção realizada pelo Estado em tal conteúdo. Mas se o autor é oculto, como pode o Estado agir contra ele sem, automaticamente, torná-lo visível e identificado?

Essa dificuldade pode ser contornada por duas constatações. Primeiro, mesmo que o autor não seja identificado, será sempre possível que ocorra a apreensão do material publicado de forma anônima, fato que atinge não apenas o direito de o autor (mesmo o anônimo) buscar atingir o público, elemento que integra a proteção do inciso $\mathrm{IV},{ }^{57}$ mas também priva o público do acesso à informação e, como consequência, afeta a função da liberdade de expressão de opiniões no que diz respeito à ampliação do debate democrático.

Segundo porque, como já foi aqui observado, as possibilidades de expressão e ação anônimas foram sensivelmente restringidas nos ambientes digitais, nos quais endereços IP, portas lógicas e outros mecanismos de rastreamento e identificação são constantemente registrados por servidores de conexão e aplicação. Por um lado, isso quer dizer que raramente uma ação é completamente anônima na internet. ${ }^{58}$ Porém, o ponto é que justamente por isso não se pode admitir que o Estado utilize a vedação do anonimato como justificativa para a identificação de toda manifestação do pensamento que ocorra em ambiente digital. Caso contrário, (i) o Estado sempre terá uma justificativa para identificar e coletar os dados de quem quer que se manifeste na internet, (ii) estará aberta a

\footnotetext{
${ }^{57}$ Nessa linha, afirmando que "expressar ou manifestar em sentido amplo abrange também o poder de divulgar, de fazer o conteúdo da expressão chegar ao seu destinatário: MARTINS (2012, p. 214).

${ }^{58}$ Nesse sentido, afirmando que sistemas automatizados de coleta e processamento de dados (Big data) tornaram a distinção entre dados anônimos e pessoais irrelevante: TENE; POLENETSKY (2013, p. 258).
} 
porta para se realizar a vigilância ostensiva da rede e também para a elaboração de dossiês de atores que se mostrem contrários à autoridade instituída ou ao pensamento dominante. ${ }^{59}$

Conscientes desses problemas, surgiram algumas propostas para contornar, ao menos em parte, suas consequências. Duas linhas argumentativas se destacam. Primeiro foi proposta uma releitura da vedação do art. 50, IV, com base em uma interpretação "flexível" de seus parâmetros. Nessa linha, sustenta-se que, uma vez que o ato de "manifestar o pensamento" ocorre das mais diversas formas e a todo momento no cotidiano, sem a necessidade de identificação prévia, então o anonimato não é algo absoluto e tão literal quanto parece. ${ }^{60}$

Dito de outra forma, se a proibição do anonimato é instrumento para eventual responsabilização, sua aplicação terá incidência somente quando houver, de fato, uma constatação definitiva do dano causado pelo conteúdo. ${ }^{61}$ Com isso, no caso da "Virada Cultural na Casa do João Doria", a citada decisão judicial, ao reconhecer a licitude da manifestação, mas exigir a identificação dos autores envolvidos na criação da página, é notoriamente infundada e inconstitucional. Não viola apenas o art. 5 $\mathrm{IV}$, da CF, mas já o princípio do Estado de direito do art. $1^{\circ}$, caput, da CF cumulado com o princípio da legalidade do art. $5^{\circ}$, II, da CF. ${ }^{62}$

Apesar de tais conclusões serem razoáveis, existem dois problemas aqui. $\mathrm{O}$ primeiro refere-se ao fato de que uma regra não ser aplicada na prática não implica, necessariamente, em um problema dogmático. O fato de um assassinato não ter sido resolvido não diz nada sobre a validade ou a consistência da norma penal que prevê o crime de homicídio; da mesma forma, o fato de muitas pessoas se manifestarem sem se identificarem não contamina, em tese, a norma que prevê a vedação do anonimato.

\footnotetext{
59 O reconhecimento de um direito fundamental à proteção de dados pessoais, ou, na terminologia alemã, de um direito à autodeterminação informacional, pode ser um fator de contenção de tais consequências, contudo, desse direito também decorrem problemas relacionados à amplitude deste conceito e da indeterminação de suas consequências. Nessa linha, reconhecendo que a indeterminação da noção de proteção de dados pode comprometer a compreensão e a aplicação deste direito: HOFFMANN-RIEM (1998, p. 516).

${ }^{60}$ Entendimento defendido pelo pesquisador Artur Péricles Lima Monteiro (2018).

${ }^{61} \operatorname{SILVA}(2021$, p. 171).

${ }^{62}$ Sobre as exigências endereçadas aos órgãos jurisdicionais e seu fundamento no princípio do Estado de direito, além de no vínculo da função jurisdicional aos direitos fundamentais como um todo, conferir MARTINS (2019, p. 45-49).
} 
Fora isso, ao pressupor que todo tipo de comunicação, desde as realizadas por jornalistas até as conversas privadas, seria igualmente afetada pela vedação do anonimato, essa tese cai na mesma armadilha dos que defendem a proibição ampla e irrestrita das comunicações anônimas: a generalização do parâmetro de proteção previsto no inciso IV. Isso não somente iguala direitos completamente diversos (os previstos nos incisos IV, XII e XVI da CF, por exemplo), como também gera problemas desnecessários (o tema da vedação de máscaras em reuniões pacíficas, por exemplo). ${ }^{63}$

Uma segunda possibilidade de compreensão é baseada na reinterpretação do "princípio distributivo", de acordo com o qual: a liberdade é a regra, sua restrição, uma exceção. ${ }^{64}$ Transportada para o âmbito da liberdade de expressão, isso indicaria que o exercício dessa liberdade deve ser, em regra, pressuposto como correto e válido; seus abusos e restrições são exceções que devem ser comprovadas. A vedação completa e sumária do anonimato inverte essa lógica por meio da presunção de que todo conteúdo anônimo é, automaticamente, abusivo. ${ }^{65}$ Mais consistente em termos filosóficos e teóricos, a presente proposta carece de parâmetros jurídico-dogmáticos específicos para ser completamente justificada. É o que se procura fazer na parte final deste texto.

\section{A reconstrução da função dogmática da vedação do anonimato}

Em termos positivos e dogmáticos, os direitos fundamentais são concebidos como normas que impõem "resistência" às ações estatais que se caracterizem como intrusivas na área de proteção garantida em nível constitucional ${ }^{66}$ Deste pressuposto decorrem três consequências. A primeira delas é que não se pode dizer que as normas de proteção de direitos fundamentais "colidem" entre si, ou

\footnotetext{
63 Contundentemente, afirmando que "[...] quem se manifesta pode se valer do anonimato, [pois] é vedado ao intérprete transplantar exclusões de tutelas pertinentes à área da vida regulamentada pelo constituinte ou limites previstos por ele a um específico direito fundamental a outro direito fundamental”: MARTINS (2017, p. 460). Semelhantemente, sustentando que o fato de os manifestantes estarem presentes na reunião afasta, por si só, o caráter anônimo da reunião: DIAS; LAURENTIIS (2014, p. 665). Para uma proposta de sistematização ampla das liberdades comunicativas, ver: FERREIRA (2021, p. 157-158).

${ }^{64}$ A formulação originária desta estrutura de pensamento é encontrada em: SCHMITT (1958, p. 192).

${ }^{65}$ Nesse sentido, conferir: BUCCI; MARANHÃO (2020).

${ }^{66}$ Para uma distinção entre as noções de direito de defesa e direito de resistência, ver: DIMOULIS; MARTINS (2021, p. $71 \mathrm{ss})$.
} 
que seja necessário realizar alguma espécie de "ponderação" ou sopesamento dos valores nelas garantidos. Isso desvirtua o sentido da proteção dessas normas, que passam a vincular não apenas o Estado, mas também a ter efeitos sobre outros direitos e terceiros, o que transforma esses direitos em fontes de obrigações.

Além disso, enquanto os valores são relativos e subjetivos, as normas jurídicas são vinculantes, do que resulta que não se pode "ponderar", "sopesar", enfim, relativizar direitos fundamentais sem automaticamente comprometer a sua estrutura de proteção. ${ }^{67}$

A segunda consequência está na impossibilidade de vinculação direta de particulares por meio de direitos fundamentais. Mais uma vez, essa conclusão é extraída da própria estrutura da proteção constitucional das normas definidoras de direitos fundamentais, que seria subvertida quando os efeitos vinculantes da norma são direcionados a outros particulares. Disso decorre não apenas a transformação das normas de garantia de direitos fundamentais em fontes de obrigações, mas também a violação da noção de reserva legal, que pode ser superada pela criação, via decisão judicial, de direitos e deveres que serão diretamente derivados de normas abstratas de proteção de direitos fundamentais.

Por fim, tem-se uma terceira consequência. Na acepção de direitos de resistência, os direitos fundamentais assumem uma característica de completude e totalidade: toda atuação estatal será avaliada com base em parâmetros de proteção de direitos fundamentais. Disso resulta que ou essa ação será considerada válida ou será inválida. Em ambos os casos, os direitos fundamentais atuam imediatamente sobre a conduta estatal (definindo parâmetros de avaliação normativa e servindo de fundamento para a invalidação de atos normativos) e mediatamente sobre a conduta dos afetados pela norma estatal avaliada (afastando a alegação do vício de inconstitucionalidade ou eliminando a regra de restrição dos direitos em discussão).

Uma vez que se declare a invalidade da norma que prevê o dever de indenização das plataformas digitais, por exemplo, conclusão que pode ser fundamentada na liberdade de comunicação social ou de livre iniciativa, a consequência será a redistribuição dos direitos afetados por essa norma; no caso, retira-se o direito à indenização daquele que se julga afetado e se confere maior

${ }^{67}$ Por todos, nesse sentido: BÖCKENFÖRDE (1991, p. 69). 
amplitude à garantia da liberdade de comunicação social exercida em ambiente digital. Os efeitos dos direitos fundamentais nas relações interpessoais ocorrem, portanto, de maneira reflexa (na medida em que as normas que foram avaliadas com base nesses parâmetros atingem os titulares dos diferentes direitos) e total (não há ramo do direito ou ação estatal que escape à força vinculante dos direitos fundamentais).

De tudo isso resulta que o sistema jurídico no qual os direitos fundamentais são garantidos não tem lacunas ou zonas de não regulamentação. Nele, o caráter reflexivo dos direitos fundamentais atua como norma de fechamento e distribuição de direitos. ${ }^{68}$ Se isso é certo, a norma contida no art. $5^{\circ}$, IV, da CF pode ser reinterpretada de duas maneiras, que ao final coincidem em suas consequências e em sua estrutura normativa.

Na primeira hipótese, a parte final do inciso, iniciada após a vírgula que inicia a expressão condicionante "sendo vedado o anonimato", deve ser interpretada como uma espécie de tácita reserva legal qualificada (uma das espécies de limites constitucionais a direitos fundamentais), por meio da qual se autoriza a interferência legislativa no conteúdo protegido pela liberdade de manifestação do pensamento. ${ }^{69}$ Isso significa que a parte final do dispositivo não se refere propriamente ao conteúdo protegido pelo direito, mas sim à eventual ação restritiva do Estado que, pretendendo tutelar outros direitos, tem a faculdade de criar, sempre por meio de lei, condições específicas que exijam a identificação pessoal do titular do direito à liberdade de manifestação do pensamento.

Tais condições para o exercício do direito podem ser justificadas quer pela importância da situação em que a manifestação do pensamento ocorre (ex: durante o período eleitoral, em comícios e por candidatos), quer em função das possíveis consequências do discurso a ser proferido (manifestações durante uma passeata de uma pessoa célebre, em que possíveis atentados possam ocorrer - como o caso do Papa João Paulo II - e, por isso, é proibido o exercício da liberdade de forma anônima durante o evento). No âmbito da internet, um exemplo de intervenção por meio da concretização da vedação do anonimato seria uma lei que exija a identificação prévia dos usuários para cadastro nas plataformas digitais

\footnotetext{
${ }^{68}$ Nesse sentido, afirmando que "Die Geltungsfunktion der Grundrechte reißt keine Löcher in die Rechtsordnung": POSCHER (2003, p. 192).

${ }^{69}$ Essa hipótese foi identificada em apenas uma obra: MENDES; BRANCO (2018, p. 399).
} 
(como ocorreu com o PL no 2.630/2020), ${ }^{70}$ ou a retenção de dados pessoais pela plataforma para futura identificação, semelhantemente ao que já ocorre com o art. $15^{\circ}$ do Marco Civil da Internet (Lei Federal no 12.965/2014). ${ }^{71}$

Não obstante, importa saber que tal dever de identificação (até independentemente da aplicabilidade do art. $5^{\circ}$, IV, da CF) deve ser previsto em lei em sentido formal, que deverá especificar a finalidade da obrigação nela imposta. Caso contrário, uma vez que se admita a identificação geral e irrestrita de todos os titulares do direito, como aludido, além do direito à liberdade de manifestação do pensamento também outros direitos fundamentais e a própria possibilidade de avaliação da restrição imposta serão inviabilizados, pois a restrição geral e sem fins específicos pode ser falaciosamente "justificada" sob os mais variados aleatórios argumentos. ${ }^{72}$

Essas conclusões são reforçadas pela dogmática constitucional brasileira, que ainda vincula o dever de identificação à eventual responsabilidade do titular pelo conteúdo da mensagem expressada. Isso faz com que a vedação do anonimato seja transformada em uma reserva legal qualificada, pois se destina a concretizar os comandos normativos previstos nos incisos $\mathrm{V}$ e $\mathrm{X}$ do art. $5^{\circ}$.

Contra estas conclusões está o perigo de se criar reservas legais por via interpretativa, pois o inciso IV em nenhum momento diz explicitamente que o conteúdo do direito pode ser condicionado ou regulamentado pela aprovação de lei (ao contrário do que ocorre nos incisos XII e XIII, por exemplo). Isso é perigoso, pois, se a Constituição previu que determinados direitos podem ser condicionados pela criação de lei e outros não, deve haver uma diferença na forma e nos efeitos da proteção de cada uma dessas hipóteses. Mas quando se admite que todo direito fundamental traz, explícita ou implicitamente, uma reserva legal, o resultado é a nivelação de todos os direitos fundamentais em

\footnotetext{
${ }^{70}$ COALIZÃO (2020).

${ }^{71}$ Art. 15. O provedor de aplicações de internet constituído na forma de pessoa jurídica e que exerça essa atividade de forma organizada, profissionalmente e com fins econômicos deverá manter os respectivos registros de acesso a aplicações de internet, sob sigilo, em ambiente controlado e de segurança, pelo prazo de 6 (seis) meses, nos termos do regulamento.

72 Nessa linha, cf. também: POSCHER (2016, p. 59-76).
} 
um mesmo nível de proteção e, como consequência, a eliminação das diferenças normativas criadas pela Constituição. ${ }^{73}$

Em paralelo, a segunda alternativa é considerar a vedação do anonimato como um dever fundamental. Neste ponto, o título do Capítulo em que o dispositivo (art. 5 IV) está inserido auxilia a fundamentação: como ali estão contidos não somente direitos, mas também deveres individuais e coletivos, nada impede que um dos incisos do art. $5^{\circ}$ contenha um dever destinado ao indivíduo que expressa o pensamento.

Isso faria com que o dispositivo possa ser seccionado em duas partes autônomas, ambas direcionadas ao titular do direito à liberdade de expressão: enquanto na primeira parte se concede o direito à livre manifestação do pensamento de forma ampla e sem vincular essa ação a nenhuma finalidade pré-determinada, o segundo período criaria um dever acoplado ao direito, dever esse a ser cumprido por todo aquele que pretenda exercer o direito previsto no primeiro período.

Fundamentada no texto da CF e coerente com a tradição da dogmática brasileira que exige do titular do direito responsabilidade em seu exercício, essa orientação é perigosa e enfrenta algumas dificuldades.

A primeira delas também tem base textual: como o $\$ 1^{\circ}$ do art. $5^{\circ}$ da CF prevê a aplicabilidade imediata apenas das normas definidoras de direitos e garantias fundamentais, os deveres, mesmo os fundamentais, não são dotados da mesma eficácia jurídica e, portanto, sua aplicação deve ser intermediada por lei. Por outro lado e a despeito do claro teor do art. $5^{\circ}, \$ 1^{\circ}$, da CF, ocorre com os deveres fundamentais o que ocorre com os direitos fundamentais de todas as categorias. Não é à toa que o Legislativo foi alcunhado de Primeiro Poder: a função legislativa formal do Estado é a primeira vinculada ao imperativo deôntico derivado das normas definidoras de direitos e deveres fundamentais. Isso explica por que, no caso dos direitos fundamentais sociais, por exemplo, do art. $6^{\circ}$ da CF, o legislador formal é chamado a cumprir seu dever de ação, ao contrário do que ocorre com os direitos de status negativus como o direito fundamental em tela que se observa mediante cumprimento de um dever de abstenção. No caso dos deveres fundamentais, o legislador é chamado a configurá-los

\footnotetext{
${ }^{73}$ De modo similar, afirmando que tentativas de generalização do padrão de proteção dos direitos fundamentais geram a maioria das dificuldades interpretativas hoje enfrentadas pela dogmática alemã: BUMKE (1998, p. 37).
} 
infraconstitucionalmente de modo mais taxativo possível, a fim de fazer jus ao princípio do Estado de direito e ao princípio da legalidade.

Os dispositivos que tratam dos direitos do autor (XXVII e XXVIII) podem gerar efeitos sobre aqueles que queiram utilizar economicamente obras artísticas, mas o texto constitucional também aqui condiciona tais efeitos à interposição legislativa. Isso indica que não se pode pressupor a existência de uma relação sinalagmática entre os direitos e os deveres fundamentais, o que quer dizer que (i) não se pode deduzir, de um direito fundamental, um dever geral equivalente, sob pena de se anular a autonomia privada, e, como consequência, (ii) para terem eficácia, os deveres necessitam, como afirmado, de concretização legislativa porque, de resto, não há uma relação de equivalência entre a aplicabilidade de direitos e deveres fundamentais. ${ }^{74}$

Como consequência, seria possível dizer que, ao acoplar a liberdade de manifestação de pensamento ao dever de identificação dos seus titulares, a CF correlacionou duas normas estruturalmente diversas no mesmo dispositivo: a primeira contém um direito com aplicação imediata e confere ao titular a faculdade de expressar seus juízos de fato ou de valor de forma livre e desimpedida; a segunda contém um dever que exige interposição legislativa para ser efetivado e que, uma vez posto em prática, condiciona o exercício do direito previsto no primeiro período, ao mesmo tempo em que facilita e estimula, sempre com base na lei, a responsabilização individual pelo conteúdo da manifestação do pensamento veiculada. ${ }^{75}$

Esse esforço reconstrutivo solucionaria a questão não fosse um último detalhe. É que, em termos práticos e dogmáticos, a última solução (considerar a vedação do anonimato como um dever fundamental) identifica-se com a primeira proposta de abordagem do problema (considerar a mesma vedação como um caso de reserva de lei).

De fato, do ponto de vista prático, como ambas as alternativas exigem interposição legislativa para a realização do comando constitucional que veda o anonimato, o resultado é que (i) enquanto não há lei que proíba este ato, todos podem se manifestar de forma anônima em ambientes virtuais ou físicos e

\footnotetext{
${ }^{74}$ DIMOULIS; MARTINS (2021, p. 84-85).

${ }^{75}$ Nessa linha, propondo a reconstrução do dispositivo: GRIZOTTO; MARTINS; LAURENTIIS (2020).
} 
(ii) as leis em que esteja prevista a exigência de identificação deverão ser consideradas, em ambas as hipóteses, como normas de intervenção na liberdade de manifestação do pensamento e, por isso, estarão sujeitas ao controle material de sua constitucionalidade com fundamento no exame da proporcionalidade como critério de possível justificação de intervenções estatais em determinada liberdade (avaliação de hipótese de violação da liberdade com base em parâmetros constitucionais específicos).

No entanto, enquanto reservas legais, mesmo qualificadas, estão à disposição do legislador, ou seja, delas se valerá conforme seu juízo de conveniência e oportunidade, no caso da presença de um dever fundamental, tal qual no caso dos direitos prestacionais, a omissão total de regulamentação é violadora do dever fundamental e, portanto, inconstitucional.

Assim, restam claras as limitações dogmáticas dos deveres fundamentais: sua atualização não prescinde da interposição legislativa. Caso o legislador cumpra seu (suposto) dever de legislar, a aplicação da regra protetiva passa a ser um problema de aplicação da lei. Quando se passa para a análise da validade da lei concretizadora do dever fundamental, não há mais "deveres fundamentais ao lado de direitos fundamentais, mas intervenções [em direitos fundamentais] como [no caso de] todas as demais obrigações legalmente determinadas". ${ }^{76}$

Identificadas sob o ponto de vista prático e dogmático, ambas as soluções ao menos apontam para o mesmo caminho: é necessário tratar o inciso IV como um conjunto normativo complexo, sob pena de tal dispositivo ter pouco ou nenhum sentido para a proteção da liberdade de manifestação do pensamento.

\section{Conclusão}

Investigar as consequências e os aspectos jurídicos da vedação constitucional do anonimato prevista no art. $5^{\circ}$, IV, da CF foi o objeto deste trabalho. Essa disposição é de difícil classificação e operacionalização jurídico-dogmática, o que gera inconsistências normativas nas posições da jurisprudência e da literatura constitucionais e, em última análise, prejudica a própria proteção jurídica do direito fundamental à liberdade de manifestação do pensamento.

${ }^{76}$ KINGREEN; POSCHER (2020, p. 83). 
Após uma revisão do contexto sociopolítico que circunda a noção do anonimato e das posições correntes na literatura e na jurisprudência, o trabalho indica duas alternativas para enquadramento dogmático da vedação constitucional do anonimato: uma reserva legal qualificada ou um dever fundamental.

Embora nenhuma das posições seja perfeita e isenta de críticas, constituem sólidos caminhos alternativos às interpretações e aplicações recorrentes. Seja como for, independente da alternativa adotada, um resultado dogmático e prático comum para ambas é a necessidade de lei específica (concretização infraconstitucional) para aplicação dessa vedação, a qual estará sujeita ao exame de constitucionalidade em face do próprio direito fundamental à liberdade de manifestação do pensamento. Por isso, não é possível, por exemplo, a aplicação direta dessa vedação pelo Poder Judiciário.

No entanto, a melhor solução para o problema seria retirar ou reformular tecnicamente o texto constitucional por meio de uma Emenda. Nessa linha, o dispositivo do art. $5^{\circ}$, IV, da CF poderia ser ajustado no sentido de nele se inserir expressamente uma reserva legal qualificada. Isso traria maior clareza e consistência dogmática.

Com a intensificação dos problemas surgidos na era digital, tanto as legislações que buscam controlar comunicações anônimas tendem a crescer como a judicialização direta de casos pontuais e, por isso, o correto manuseio dos dispositivos constitucionais torna-se imprescindível para que se realize uma operacionalização adequada do controle de constitucionalidade. Contribuir com essa tarefa foi o principal objetivo desta pesquisa e deste artigo.

\section{Referências}

ASCHER, Diana L.; UMOJA NOBLE, Safiya. Unmasking hate on Twitter: disrupting anonymity by tracking trolls. In: BRISON, Susan J.; GELBER (ed.). Free speech in the digital age. Oxford: Oxford University Press, 2019.

BADARÓ, Gustavo Righi Ivahy. Processo penal brasileiro. São Paulo: Revista dos Tribunais, 2017. 
BARBOSA, Rui. A Constituição de 1891. Rio de Janeiro: Ministério da Educação e Saúde, 1946. 379 p. (Obras completas de Rui Barbosa, v. 17, t. 1, 1890). Disponível em: https://bibliotecadigital.stf.jus.br/xmlui/bitstream/ handle/123456789/235/5433.pdf?sequence=1\&isAllowed=y. Acesso em: 15 nov. 2021.

BARBOSA, Rui. A ditadura de 1893: Jornal do Brasil. Rio de Janeiro: Ministério da Educação e Saúde, 1949. (Obras completas de Rui Barbosa ; v. 20, t. 2, 1893) Disponível em: http://biblioteca2.senado.gov.br:8991/F/R4XTFXTSBK6RAI3 C6P61IXQ46T2JN2CI6C45JYYADK54HHMGGE-29790? func=service\&doc library=SEN01\&doc_number $=000005352 \&$ line_number $=0001 \&$ func_ code=WEB-FULL\&service_type=MEDIA\%22. Acesso em: 15 nov. 2021.

BECKER, Howard S. Outsiders: studies in the sociology of deviance. New York: The Free Press, 1997.

BÖCKENFÖRDE, Ernst-Wolfgang. Die methoden der verfassungsinterpretation. In: BÖCKENFÖRDE, Ernst-Wolfgang. Staat, verfassung, demokratie. Frankfurt am Main: Suhrkamp, 1991.

BUCCI, Eugênio; MARANHÃO, Juliano. Não podemos jogar fora direito ao anonimato para combater fake news. Jornal Folha de São Paulo, 16 jun 2020. Disponível em: https://bityli.com/IZsIfO. Acesso em: 1o jun. 2021.

BUMKE, Christian. Der grundrechtsvorbehalt: untersuchungen über begrenzung und ausgestaltung der grundrechte. Baden-Baden: Nomos, 1998.

COALIZÃO DE DIREITOS NA REDE. PL das $\boldsymbol{f} \boldsymbol{a} \boldsymbol{k} \boldsymbol{e} \boldsymbol{n} \boldsymbol{e w s}$ : identificação e criminalização em massa de usuários. [Porto Alegre], 20 jun. 2020. Disponível em: https://direitosnarede.org.br/2020/06/20/pl-das-fake-news-identificacaoe-criminalizacao-em-massa-de-usuarios/. Acesso em: 28 set. 2021.

COLEMAN, Gabriella. How has the fight for anonymity and privacy advanced since Snowden's whistle-blowing? Media, Culture \& Society, vol. 41, n. 4, p. 565-571, 2019.

DIAS, Roberto; LAURENTIIS, Lucas Catib de. Liberdade de reunião e democracia: reflexões a partir das experiências brasileiras e alemãs. Revista Brasileira de Estudos Constitucionais - RBEC, v. 8, n. 30, p. 649-669, set./dez. 2014. 
DIMOULIS, Dimitri; MARTINS, Leonardo. Teoria geral dos direitos fundamentais. 8. ed. , rev., atual. e ampl.. São Paulo: Thomson Reuters Revista dos Tribunais, 2021.

FARIAS, Edilsom Pereira de. Liberdade de expressão e comunicação: teoria e proteção constitucional. 2001. 287 f. Tese (Doutorado em Direito) Centro de Ciências Jurídicas, Universidade Federal de Santa Catarina, Florianópolis, 2001. Disponível em: https://repositorio.ufsc.br/xmlui/bitstream/ handle/123456789/79426/182787.pdf?sequence=1\&isAllowed=y. Acesso em: 15 nov. 2021.

FERRAZ JÚNIOR, Tércio Sampaio. Sigilo de dados: o direito à privacidade e a função fiscalizadora do Estado. Revista da Faculdade de Direito, Universidade de São Paulo, v. 88, p. 439-459, jan./dez. 1993. Disponível em: https://www. revistas.usp.br/rfdusp/article/view/67231/69841. Acesso em: 15 nov. 2021.

FERREIRA, Felipe Grizotto. Liberdade de expressão na era digital: desafios, perspectivas e aplicações. 2021. 225 f. Dissertação (Mestrado em Direito) - Centro de Ciências Humanas e Sociais Aplicadas, Pontifícia Universidade Católica de Campinas, Campinas, São Paulo, 2021. Disponível em: http://tede.bibliotecadigital. puc-campinas.edu.br:8080/jspui/bitstream/tede/1446/2/FELIPE\%20GRIZO TTO\%20FERREIRA.pdf. Acesso em: 15 nov. 2021.

GRIZOTTO, Felipe Ferreira; MARTINS, Leonardo; LAURENTIIS, Lucas Catib. Regulação de plataformas digitais, anonimato e o sistema constitucional brasileiro. JOTA, 10 ago. 2020. Disponível em: https://www.jota.info/coberturas-especiais/ liberdade-de-expressao/regulacao-das-plataformas-digitais-anonimato-e-osistema-constitucional-brasileiro-10082020. Acesso em: 27 maio 2021.

HAMILTON, Alexander; JAY, John; MADISON, James. The Federalist: a commentary on the Constitution of United States. New York: Modern Library, Random House, 1937.

HARTMANN, Bernd. Dienende freiheit: notwendige verstärkung oder widersprüchliche beschränkung subjektiver Rechte? JuristenZeitung - JZ, v. 71, n. 1, p. 18-26, Jan. 2016.

HOFFMANN-RIEM, Wolfgang. Informationelle selbstbestimmung in der informationsgesellschaft - auf dem wege zu einem neuen konzept des datenschutzes. Archiv des öffentlichen Rechts, v. 123, n. 4, p. 513-540, 1998. 
HOROWITZ, Sarah. Foucault's panopticon: a model for NSA surveillance? In: MILLER, Russell A. (ed.). Privacy and power. Cambridge: Cambridge University Press, 2017.

KINGREEN, Thorsten; POSCHER, Ralf. Grundrechte Staatsrecht II. 36. ed. Heidelberg: CF Müller, 2020.

LAURENTIIS, Lucas Catib de. A proporcionalidade no direito constitucional: origem, modelos e reconstrução dogmática. São Paulo: Malheiros, 2017.

MACHADO, Jónatas. Liberdade de expressão: dimensões constitucionais da esfera pública no sistema social. Coimbra: Coimbra Editora, 2002.

MARTINS, Leonardo. Direito fundamental à liberdade de reunião e controle de constitucionalidade de leis penais e de sua interpretação e aplicação: contribuição para o direito de reunião como sub-ramo autônomo do direito administrativo. Espaço Jurídico Journal of Law - EJJL, v. 18, n. 2, p. 433-490, 2017. Disponível em: https://doi.org/10.18593/ejjl.13301. Acesso em: 16 nov. 2021.

MARTINS, Leonardo. Direitos fundamentais à intimidade, à vida privada, à honra e à imagem (art. 50, $\mathrm{X}$ da $\mathrm{CF}$ ): alcance e substrato fático da norma constitucional (intervenção estatal potencialmente violadora). Ius Gentium, v. 7, n. 1, p. 105-132, 2016. Disponível em: https://www.revistasuninter.com/ iusgentium/index.php/iusgentium/article/view/234/181.

MARTINS, Leonardo. Liberdade e Estado constitucional: leitura jurídicodogmática de uma complexa relação a partir da teoria liberal dos direitos fundamentais. São Paulo: Atlas, 2012.

MARTINS, Leonardo. Questões constitucionais na ordem processual: entre a repercussão geral e a tutela de direitos fundamentais individuais. Espaço Jurídico Journal of Law - EJJL, v. 20, n. 1, p. 21-79, 2019. Disponível em: https://doi. org/10.18593/ejjl.19953. Acesso em: 16 nov. 2021.

MARTINS, Leonardo. Tribunal constitucional federal alemão: decisões anotadas sobre direitos fundamentais. São Paulo: Konrad-Adenauer-Stiftung, 2018. v. 2. Disponível em: https://www.kas.de/c/document_library/get_ file? uuid=0e7ecfea-de6a-87b3-51c5-fc624f9ffe47\&groupId=252038. Acesso em: 16 nov. 2021.

MENDES, Gilmar Ferreira; BRANCO, Paulo Gustavo Gonet. Curso de direito constitucional. 13. ed., rev. e atual. São Paulo: SaraivaJur, 2018. 
MONTEIRO, Artur Lima Péricles. Online anonymity in Brazil: identification and the dignity in wearing a mask. 2017. Dissertação (Mestrado em Direito do Estado) - Faculdade de Direito, Universidade de São Paulo, São Paulo, 2017.

MONTEIRO, Artur Pericles Lima. Proibição do anonimato no Brasil tem sido usada para justificar censura judicial. Revista Consultor Jurídico, 30 set. 2018. Comentário de, Carlos de Azevedo Senna na entrevista concedida à Revista. Disponível em: https://bityli.com/3PVsIK. Acesso em: $1^{\circ}$ jun. 2021.

MOORE, Martin. Democracy hacked: political turmoil and information warfare in the digital age. London: Oneworld, 2018.

NISSENBAUM, Helen, The meaning of anonymity in an information age. The Information Society, v. 15, n. 2, p. 141-144, 1999.

NOVELINO, Marcelo. Direito constitucional. 6. ed. , rev., atual. e ampl. São Paulo: Método, 2012.

NOVA versão de lei contra fake news terá restrições a contas anônimas e mais poder a denúncias de usuários. Senado Notícias, 2 jun. 2020. Disponível em: https://bityli.com/UFcYeT. Acesso em: 8 ago. 2021

NUCCI, Guilherme de Souza. Manual de direito penal. 13. ed., rev., atual. e ampl. Rio de Janeiro: Forense, 2017.

OMER, Corey. Intermediary liability for harmful speech: lessons from abroad. Harvard Journal of Law \& Technology, v. 28, n. 1, p. 289-324, 2014. Disponível em: http://jolt.law.harvard.edu/articles/pdf/v28/28HarvJLTech289.pdf. Acesso em: 16 nov. 2021.

PIRES, Breiller. Ações judiciais tentam revelar identidade de administrador do Sleeping Giants, Él País, São Paulo, 25 ago. 2020. Disponível em: https://bityli. com/po94WS. Acesso em: 10 out. 2020.

POSCHER, Ralf. Grundrecht als abwehrrecht: reflexive regelung rechtlich geordneter Freiheit. Tübingen: Mohr Siebeck, 2003.

POSCHER, Ralf. Tendencies in public civil security law. European Journal for Security Research, v. 1, n. 1, p. 59-76, 2016. Disponível em: https://link.springer. com/content/pdf/10.1007/s41125-016-0003-3.pdf. Acesso em: 16 nov. 2021. 
QUEIROZ, Rafael Mafei Rabelo. A concepção restrita de anonimato e a opção pela intervenção de menor intensidade. Suprema: Revista de Estudos Constitucionais, v. 1, n. 1, p. 241-266, 2021. Disponível em: https://suprema.stf.jus.br/index.php/ suprema/article/view/24. Acesso em: 16 nov. 2021.

RODOTÀ, Stefano. A vida na sociedade da vigilância: a privacidade hoje. Rio de Janeiro: Renovar, 2008.

RUBIN, Zick, Disclosing oneself to a stranger: reciprocity and its limits. Journal of Experimental Social Psychology, v. 11, n. 3, p. 233-260, 1975.

SARDÁ, Thais et al. Understanding online anonymity. Media, Culture \& Society, v. 41, n. 4, p. 557-564, 2019.

SARLET, Ingo Wolfgang; MARINONI, Luiz Guilherme; MITIDIERO, Daniel. Curso de direito constitucional. 7. ed. , rev., atual. e ampl. São Paulo: Saraiva Educação, 2018.

SARMENTO, Daniel. [Comentários ao] artigo 5º, [inciso] IV. In: CANOTILHO, J. J. Gomes et al. (coord.). Comentários à Constituição do Brasil. São Paulo: Saraiva; Almedina, 2013.

SCHAUER, Frederick. Fear, risk and the First Amendment: unraveling the chilling effect. Boston University Law Review, v. 58, p. 685-732, 1978. Disponível em: https://scholarship.law.wm.edu/cgi/viewcontent. cgi? article $=2010 \&$ context $=$ facpubs. Acesso em: 16 nov. 2021 .

SCHMITT, Carl. Grundrechte und grundpflichten. In: SCHMITT, Carl. Verfassungsrechtliche aufsätze aus den jahren 1924-1954. Berlin: Duncker und Humblot, 1958.

TAYLOR, Miles. I am part of the resistance inside the Trump Administration. The New York Times, 5 set. 2018). Disponível em: https://www.nytimes. com/2018/09/05/opinion/trump-white-house-anonymous-resistance.html. Acesso em: 15 nov. 2021.

SILVA, José Afonso da. Comentário contextual à Constituição. 8. ed., atual. até a Emenda Constitucional 70, de 22.12.2011. São Paulo: Malheiros, 2012.

SILVA, Virgílio Afonso da. Direito constitucional brasileiro. São Paulo: Edusp, 2021. 
SOLOVE, Daniel J. Understanding privacy. Cambridge: Harvard University Press, 2008.

SOLOVE, Daniel. The virtues of knowing less: justifying privacy protections against disclosure. Duke Law Journal, v. 53, n. 3, p. 967-1067, dec. 2003. Disponível em: https://scholarship.law.duke.edu/cgi/viewcontent. cgi article $=1213 \&$ context $=$ dlj. Acesso em: 16 nov. 2021 .

TENE, Omer; POLENETSKY, Jules. Big data for all: Privacy and user control in the age of analytics. Northwestern Journal of Technology and Intellectual Property, v. 11, n. 5, p. 240-272, apr. 2013. Disponível em: https://scholarlycommons.law.northwestern.edu/cgi/viewcontent. cgi article=1191\&context=njtip. Acesso em: 16 nov. 2021 .

TUFEKCI, Zeynep. Twitter and tear gas: the power and fragility of networked protest. New Haven: Yale University Press, 2017.

\section{Jurisprudência citada}

ALEMANHA. Bundesverfassungsgericht. Soldaten sind mörder. Bundesverfassungsgerichtsentscheidungen - BVerfGE, v. 93, p. 266-300?, 1995. Disponível em: https://www.servat.unibe.ch/dfr/bv093266.html. Acesso em: 16 nov. 2021

BRASIL. Supremo Tribunal Federal (1. Turma). Habeas Corpus 84.827/TO. Relator: Min. Marco Aurélio, 7 de agosto de 2007. Disponível em: https://redir. stf.jus.br/paginadorpub/paginador.jsp?docTP=AC\&docID=495536. Acesso em: 18 nov. 2021.

BRASIL. Supremo Tribunal Federal (Decisão Monocrática). Medida Cautelar no Mandado de Segurança 24.369/DF. Relator: Min. Celso de Mello, 10 de dezembro de 2002. Diário da Justiça Eletrônico: Supremo Tribunal Federal, n. 200, 16 out. 2002. Disponível em: http://stf.jus.br/portal/diarioJustica/ver Decisao.asp? numDj $=200 \&$ dataPublicacao $=16 / 10 / 2002 \&$ incidente $=3700653 \&$ capitulo $=6 \&$ codigoMateria $=2 \&$ numeroMateria $=155 \&$ texto $=1234872$. Acesso em: 18 nov. 2021.

ESTADOS UNIDOS DA AMÉRICA. Supreme Court. New York Times Co. v. Sullivan. Justia US Supreme Court, v. 376, p. 254-305?, 1964. Disponível em: https://supreme.justia.com/cases/federal/us/376/254/. Acesso em: 16 nov. 2021. 


\section{Legislação citada}

BRASIL. [Constituição (1988)]. Constituição da República Federativa do Brasil de 1988. Brasília, DF: Presidência da República, [2021]. Disponível em: http://www.planalto.gov.br/ccivil_03/constituicao/constituicao.htm. Acesso em: 16 nov. 2021.

BRASIL. Emenda Constitucional no 1, de 17 de outubro de 1969. Edita o novo texto da Constituição Federal de 24 de janeiro de 1967. Brasília, DF: Presidência da República, [1988]. Disponível em: http://www.planalto.gov.br/ccivil_03/ constituicao/emendas/emc_anterior1988/emc01-69.htm. Acesso em: 17 nov. 2021.

BRASIL. Lei no 4.737, de 15 de julho de 1965. Institui o Código Eleitoral. Brasília, DF: Presidência da República, [2021]. Disponível em: http://www.planalto.gov. br/ccivil_03/leis/14737compilado.htm. Acesso em: 16 maio 2021.

BRASIL. Lei no 9.610, de 19 de fevereiro de 1998. Altera, atualiza e consolida a legislação sobre direitos autorais e dá outras providências. Brasília, DF: Presidência da República, [2021]. Disponível em: http://www.planalto.gov.br/ ccivil_03/leis/19610.htm. Acesso em: 17 nov. 2021.

BRASIL. Lei no 12.965, de 23 de abril de 2014. Estabelece princípios, garantias, direitos e deveres para o uso da Internet no Brasil. Brasília, DF: Presidência da República, [2021]. Nota: Marco civil da internet. Disponível em: http://www. planalto.gov.br/ccivil_03/_ato2011-2014/2014/lei/112965.htm. Acesso em: 16 nov. 2021.

BRASIL. Senado Federal. Projeto de Lei n 2630, de 13 de maio de 2020. Institui a Lei Brasileira de Liberdade, Responsabilidade e Transparência na Internet. Brasília, DF: Senado Federal, [2021]. Nota: Lei das Fake News. Tramitação disponível em: https://www25.senado.leg.br/web/atividade/materias/-/ materia/141944. Acesso em: 16 nov. 2021. 